\begin{tabular}{c|c|c|} 
CRITICAL & $\begin{array}{l}\text { WCOSYSTEM } \\
\text { PARTNERSHIP FUND }\end{array}$ & $\begin{array}{l}\text { Western Ghats } \\
\text { Special Series }\end{array}$ \\
\cline { 2 - 3 } & Meghamalai special section \\
\cline { 3 - 3 } &
\end{tabular}

\title{
MAMmals OF THE MEghamalal LANDSCAPE, SOUTHERN WESTERN GHATS, INDIA - A REVIEW
}

\author{
Santhanakrishnan Babu ${ }^{1}$, Gopalakrishnan Srinivas ${ }^{2}$, Honnavalli N. Kumara ${ }^{3}$, \\ Karthik Tamilarasu ${ }^{4}$ \& Sanjay Molur ${ }^{5}$
}

1,3 Śalim Ali Centre for Ornithology and Natural History, Anaikatty (PO), Coimbatore, Tamil Nadu 641108, India 1,2,5 Wildlife Information Liaison Development Society, 96, Kumudham Nagar, Vilankurichi Road, Coimbatore, Tamil Nadu 641035, India

${ }^{5}$ Zoo Outreach Organization, 96, Kumudham Nagar, Vilankurichi Road, Coimbatore, Tamil Nadu 641035, India ${ }^{4}$ Department of Zoology, AVC College, Mannampandal, Mayiladuthurai, Tamil Nadu 609305, India

${ }^{1}$ sanbabs@gmail.com (corresponding author), ${ }^{2}$ sriniherp@gmail.com, ${ }^{3}$ honnavallik@gmail.com,

${ }^{4}$ karthikherp@gmail.com, ${ }^{5}$ herpinvert@gmail.com

Abstract: Reports on the concurrence of mammals in the Meghamalai landscape were collated from published literature and also the data obtained from a recent study spanning over 18 months (June 2011-December 2012). Sixty-three species belonging to 24 families occur in the landscape, which include 24 globally threatened (one Critically Endangered; seven Endangered; 11 Vulnerable and five Near Threatened) species. Of the recorded species, four species are endemic to India and nine are endemic to the Western Ghats. The present study added five species, viz., Rusty-spotted Cat Prionailurus rubiginosus, Malabar Spiny Tree Mouse Platacanthomys lasiurus, Grizzled Giant Squirrel Ratufa macroura, Common Palm Civet Paradoxurus hermaphrodites and the Indian Grey Mongoose Herpestes edwardsii to the six decade old mammal list. But, 13 species reported by Hutton were not recorded during the study. Among them, occurrence of Malabar Civet Viverra civettina and Fishing Cat
Prionailurus viverrinus in southern India remains unresolved. During our study, anthropogenic pressures such as conversion of natural habitats, encroachment, hunting, cattle grazing and tourism were observed to affect the distribution of mammals in the landscape.

Keywords: Arboreal mammals, conservation issues, endemism, species richness, Western Ghats.

The Meghamalai landscape is situated in the northeastern side of Periyar Tiger Reserve, encompassing High Wavy Mountains, Varusanad Valley and Hill, and Vellimalai. High Wavy Mountains is popularly referred

DOI: http://dx.doi.org/10.11609/JoTT.o3596.4945-52 | ZooBank: urn:Isid:zoobank.org:pub:8F2C191C-691F-4CD8-A019-587E8F9FA11E

Editor: Mewa Singh, Mysore University, Mysuru, India.

Date of publication: 26 November 2013 (online \& print)

Manuscript details: Ms \# 03596 | Received 26 April 2013 | Final received 03 August 2013 | Finally accepted 05 October 2013

Citation: Babu, S., G. Srinivas, H.N. Kumara, K. Tamilarasu \& S. Molur (2013). Mammals of the Meghamalai landscape, southern Western Ghats, India - a review. Journal of Threatened Taxa 5(15): 4945-4952; http://dx.doi.org/10.11609/JoTT.03596.4945-52

Copyright: @ Babu et al. 2013. Creative Commons Attribution 3.0 Unported License. JoTT allows unrestricted use of this article in any medium, reproduction and distribution by providing adequate credit to the authors and the source of publication.

Funding: This work is part of the ATREE-CEPF and Rufford Small Grant research project and we appreciate them for the financial support.

Competing Interest: The authors declare no competing interests.

Acknowledgements: We thank Tamil Nadu Forest Department and Theni Forest Division for the permission to carry out this study; the directors and other colleagues in SACON and WILD for the facilities and support; VANAM and WAR for their logistic support during field work.
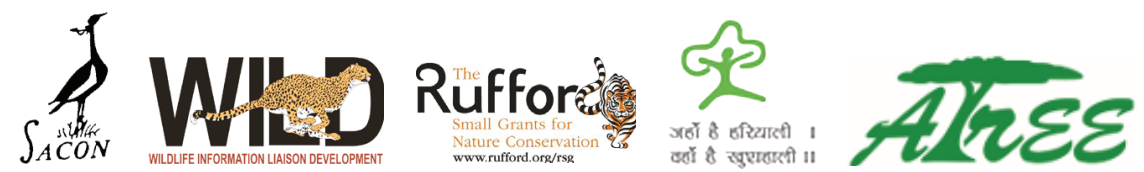

This article forms part of a special series on the Western Ghats of India, disseminating the results of work supported by the Critical Ecosystem Partnership Fund (CEPF), a joint initiative of I'Agence Française de Développement, Conservation International, the European Commission, the Global Environment Facility, the Government of Japan, the MacArthur Foundation and the World Bank. A fundamental goal of CEPF is to ensure civil society is engaged in biodiversity conservation. Implementation of the CEPF investment program in the Western Ghats is led and coordinated by the Ashoka Trust for Research in Ecology and the Environment (ATREE). 
to as 'Pachchaikoomachi' and 'Meghamalai' by locals that explicate dense forest and cloud covered hill respectively (Fig. 1). Summit ridges of the landscape receive high precipitation during the south-west and north-east monsoons and have a narrow strip of wet forests. Meghamalai forms an imperative wildlife corridor with Periyar Tiger Reserve to the south-west, Grizzled Squirrel Wildlife Sanctuary to the south and the Cumbum West forests to the north. Furthermore, it is bestowed with certain remnant patches of wet forests in high elevation plateaus $(>1400 \mathrm{~m})$, which have been severely fragmented and over-exploited for raising commercial crops and plantations that have left the natural forests as fragments or islands.

In spite of being an important wildlife corridor, updated data on mammals of the landscape is lacking. The earliest survey on mamals in the hill range was started in the beginning of the $19^{\text {th }}$ century by Prater. He explored and collected mammals from the Cumbum Valley and the northern slopes of High Wavy Mountains, and these specimens were preserved in Bombay Natural History Society (BNHS) Museum collections. Subsequently, Wroughton (1917) wrote the descriptions for collections made by Prater, from which he identified 24 species mainly of rodents and bats. After a lapse of three decades, Hutton (1949) made collections and described the behaviour, habitat and distribution of 56 mammalian species including a few range restricted and threatened species. More than two decades later (1972), while working on the specimens of megachiropterans at BNHS, Thonglongya had noticed that the specimen labelled Cynopterus sphinx, collected at the High Wavy Mountains, was wrongly identified. He identified it as a new genus Latidens and named the species Latidens salimalii (Thonglongya 1972), which is endemic to southern India. A subsequent survey by BNHS and Harrison Zoological Museum rediscovered L. salimalii at the High Wavy Tea and Coffee Estates (Kardana Coffee Estate). In addition, a few short surveys were also attempted to address the roost site characteristics of the bat (Singaravelan \& Marimuthu 2003a,b). Kumara et al. (2011) highlighted that the landscape harbours one of the largest populations of globally threatened Lion-tailed Macaque Macaca silenus. Bhupathy et al. (2012) have highlighted the conservation significance of the landscape using select vertebrates. Although the landscape has been well explored in terms of mammals over the decades (1917-2012) through a series of shortterm studies at different time periods (1917-2012), the updated list of mammals and their current status

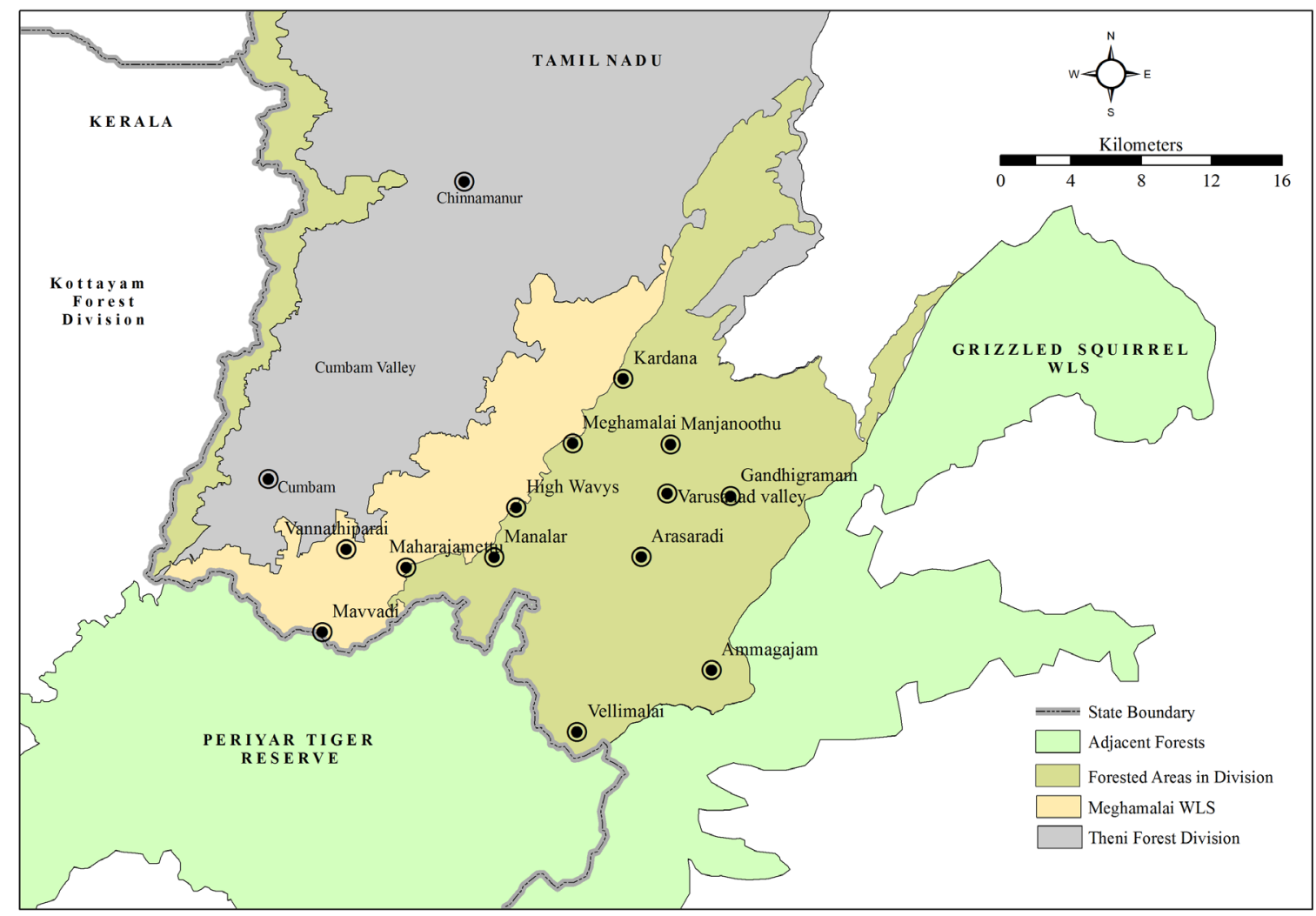

Figure 1. Surveyed areas in Meghamalai landscape, southern Western Ghats 
(qualitative) in the landscape has not been attempted. In this context, we update the mammals of the Meghamalai landscape based on primary (June 2011-December 2012) and secondary information.

\section{Materials and Methods}

We carried out a study on the status and distribution of large mammals in the landscape between June 2011 and December 2012. The entire landscape was gridded into 133 grids on the base map and each grid was sampled for the presence/absence of the mammals by walking on pre-determined paths. During these walks all sighted animals were recorded, droppings on trail were recorded with species identity, and also animal presence was recorded based on tracks and signs. We also conducted night surveys using flash lights or by using a motor vehicle with lights by driving slowly and recording animals found on either side of the road. The total sampling effort amounted to $85 \mathrm{~km}$. Further, we also reviewed the literature to prepare a comprehensive list of mammals for the landscape (Wroughton 1917; Hutton 1949; Thonglongya 1972; Muni 1994; Singaravelan \& Marimuthu 2003a,b). The status of each mammal species observed by Hutton was compared with the current population status (consolidated from the study) to understand the influence of six decades of disturbance on the distribution of large mammals (41 species). IUCN status, endemism and schedule category in Indian Wildlife Protection Act (1972) were compiled to highlight the conservation significance of the landscape in terms of mammals.

\section{Results and Discussion}

Sixty three species of mammals belonging to 24 families were recorded from the landscape. The family Muridae (rats and mouse) was recorded with a maximum number of species (Fig. 2) followed by Sciuridae (squirrels) and Felidae (cats). Among the 63 species, 24 are globally threatened (including one Critically Endangered; seven Endangered; 11 Vulnerable and five Near Threatened species), nine are endemic to the Western Ghats and four to India (Fig. 3). The number of species recorded as common (C) and very common (VC) were lower than Hutton's observation, however uncommon (UC) and rare (RR) were higher than the earlier observation (Fig. 4). Five species, viz., Rusty-spotted Cat, Malabar Spiny Tree Mouse, Indian Grey Mongoose, Grizzled Giant Squirrel and Common Palm Civet were added for the first time to the existing list of mammals in Meghamalai. Further, three species of bats, viz., Salim Ali Fruit bat Latidens salimalii, Lesser Dog-faced Fruit Bat Cynopterus brachyotis and Rufous Horseshoe Bat Rhinolophus rouxii were not recorded by Hutton though recorded by Singaravelan \& Marimuthu $(2003 a, b)$. Some of the sight records of earlier notes raise doubts of its accuracy, in particular the sightings of Malabar Civet and Fishing Cat. Detailed species information, for each new site record, obtained from the present study is presented here.

Rusty-spotted Cat Prionailurus rubiginosus: Four observations of the Rusty-spotted Cat (RSC) were obtained during the present study. This included two direct sightings (June 2012; Vannathiparai of Gudalur Range) and two indirect sightings (July 2012, a dead one found at Manjanoothu of Varusanad Valley and a road kill near Rajapalayam Town). The species presumably prefers low elevation, leeward side and next to human settlements in Meghamalai.

Malabar Spiny Tree Mouse Platacanthomys lasiurus: A single individual was located at No. 29 coffee estate,

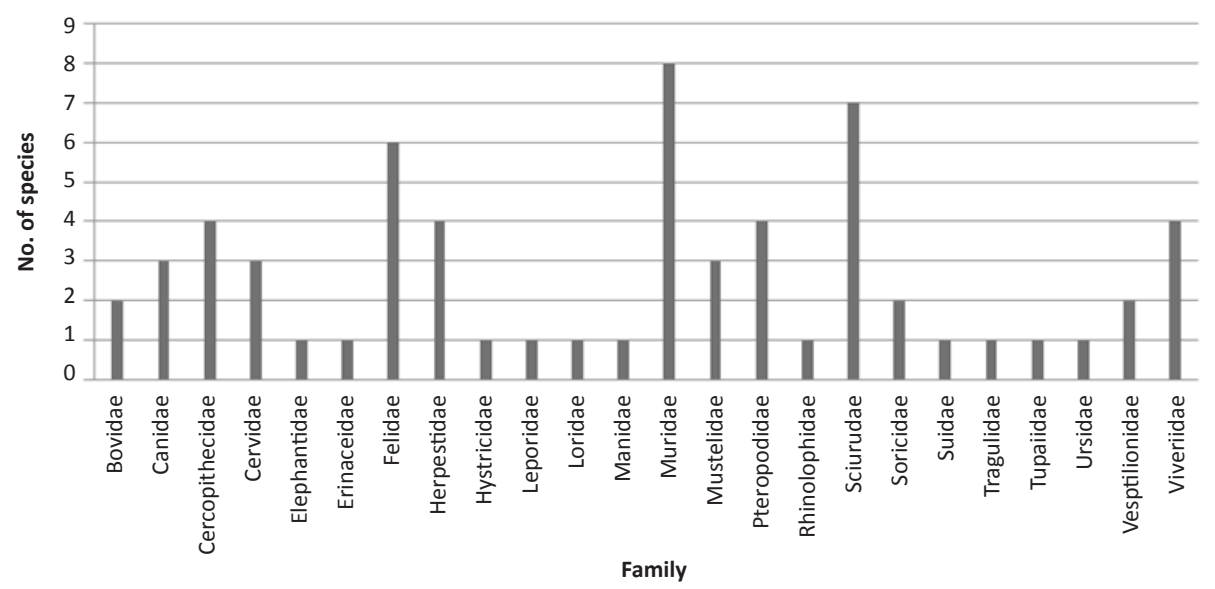

Figure 2. Family wise species richness of mammals in Meghamalai 


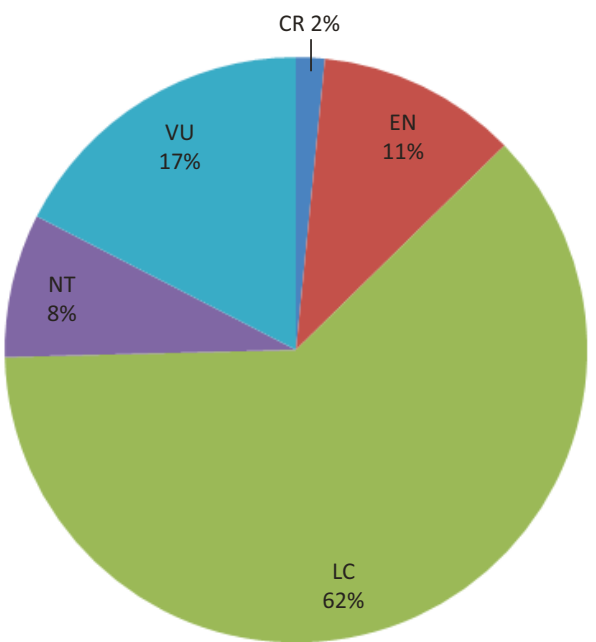

Figure 3. Threat status of mammals recorded in Meghamalai

located in the south-eastern slopes of High Wavy Mountains, at 20:00 hours on 21 December 2011 during a night survey in the coffee estate areas. It was observed on a shrub at $1.5 \mathrm{~m}$ height from the ground.

Grizzled Giant Squirrel Ratufa macroura: At five different occasions, seven individuals were observed along the tributaries and the main river of Vaigai. The western most location of the species in the Varusanad Valley is Arasaradi, where the rain-shadow region starts. The distribution of the species was confirmed down towards Gandhigramam near Kadamalaikundu and in other parts of Varusanad Valley. The hill ranges that extend towards the eastern side require an intensive survey. Although highly scattered in distribution, around 20 nests of the species were located in riparian forests in low elevations (>400m)

Indian Grey Mongoose Herpestes edwardsii: It was frequently seen in the dry zones of Varusanad Valley and the eastern portions of Meghamalai. Mostly single individuals were seen but occasionally they were observed in pairs.

Common Palm Civet Paradoxurus hermaphrodites: Although it is commonly seen along the foothills next to coconut plantations, Hutton (1949) had not reported the species during his survey. During the night survey in January 2012 at Meghamalai Tea Estate, a single individual was sighted. However, later it was found that the species had frequently been sighted in the plains than in the mountains. The species had been considered as a pest in the coconut plantations downhill.

Arboreal mammals: We recorded eight arboreal mammals including five primates, two giant squirrels and one flying squirrel. The distribution of LionTailed Macaque Macaca silenus and Nilgiri Langur

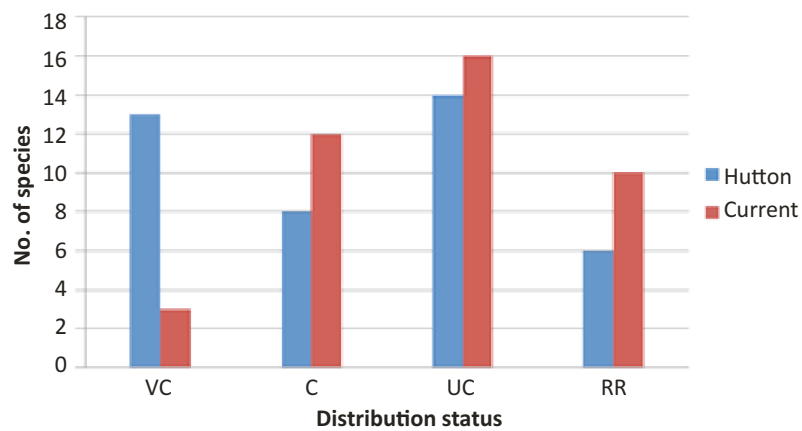

Figure 4. Comparing the abundance status of mammals in two different time periods in Meghamalai

Semnopithecus johnii was restricted to the high rainfall areas on the western side, viz., No. 29 Estate, Vellimalai, Ammagajam and Jyothi estates, whereas Bonnet Macaque Macaca radiata was recorded from all the elevation gradients while Tufted Grey Langur Semnopithecus priam was recorded only from drier forests mostly downhill. Grey Slender Loris Loris lydekkerianus was sighted frequently in the low elevation dry forests. Among giant squirrels, the Indian Giant Squirrel Ratufa indica was found in the high canopied forests of mid and high elevations, whereas a small population of Grizzled Giant Squirrel (seven individuals) was observed along the Vaigai River and its tributaries. The Indian Giant Flying Squirrel Petaurista philippensis was recorded during the night surveys in thick canopied forests areas such as Vellimalai and High Wavy estates.

Large herbivores: About 12 herds of Asian Elephant Elephas maximus were located during the survey, and the maximum herd size recorded was 10 . Frequent sightings of Asian Elephants were made in Meghamalai, High Wavy, Manalar estates, Manjanoothu, Vellimalai, Vannathiparai and Arasaradi. Gaur Bos gaurus was recorded across the hill range but direct sightings were made in the Varusanad Valley i.e., the eastern slopes of Vellimalai. Among the ungulates, Sambar Rusa unicolor was observed widely across the landscape and indirect evidence was recorded in all the sampled grids. Chital Axis axis was recorded mostly in the dry eastern plains of Varusanad Valley and northern slopes of Meghamalai. Southern Red Muntjac Muntiacus muntjak was recorded across the altitudinal gradients. Indian Chevrotain Moschiola indica was recorded and found to be highly selective in habitat utilization and during our survey most of the sightings were made from the riparian forests. Nilgiri Tahr Nilgiritragus hylocrius was recorded in Varayattu Parai and the southeastern slopes of High Wavy Mountains.

Carnivores: Although the landscape shares the 
western side with Periyar Tiger Reserve, direct and indirect evidence of Tigers Panthera tigris were mostly restricted to the western plateau of the landscape. Indirect evidence was recorded in Maavadi, upper Manalar, Vellimalai and along the forest road between upper Manalar and Vellimalai. Indirect evidence of Leopard Panthera pardus and Dholes Cuon alpinus was frequently observed across the sampling grids. Among other carnivore species, Jungle Cat Felis chaus, Leopard Cat Prionailurus bengalensis, Rusty-spotted Cat, Small Indian Civet Viverricula indica, Brown Palm Civet Paradoxurus jerdoni, and Common Palm Civet were seldom seen during the night surveys. Indian Grey and Striped-necked Mongooses Herpestes vitticollis were uncommon during the study but Ruddy (Herpestes smithii) and Indian Brown Mongoose Herpestes fuscus were observed occasionally. A single individual of Nilgiri Marten Martes gwatkinsi was sighted near the evergreen forests of Upper Manalar.

Sixty-three species of mammals are reported hitherto from the landscape. However, it is presumed that it is short of a few more species of mammals, in particular rats, mice and bats. The high species richness of mammals in the landscape can be attributed to wide elevation gradients (200-2000 m), varied rainfall pattern (rainfed and rainshadow) and highly mosaic vegetation. These characteristics of landscape endowed with diverse eco-climatic zones and niches act as a refuge for diverse species of mammals. Further, the landscape shares the corridor with important wildlife areas such as Periyar Tiger Reserve and Grizzled Squirrel Wildlife Sanctuary in the western and southern side of the landscape, and so it facilitates the mammals to utilize this area.

The scope of the present study (2012) was restricted to large mammals. Hence, bats and small rodents (rats, shrews and mice), were not considered for comparison with Hutton's (1949) anecdotal notes, as it involves capturing for species identification. Six decade-old data showed the distribution of 57 species of mammals including 41 species of large mammals, of which the persistence of 38 large mammals in the landscape was observed, and three were not recorded during the study, viz., Malabar Civet, Fishing Cat and Golden Jackal. The species level status of Malabar Civet in India remains unresolved but land-use practices in low elevations of Varusanad Valley (cashew plantations) matches with Elayur (Kozhikode District, Kerala) from where a dead specimen of the species was collected during the 1990s (Ashraf et al. 1993). Moreover, Hutton (1949) categorised the species as common in high elevations but we were informed by locals that there was no large sized civet in the landscape. This raises the question on the report by Hutton (1949). Furthermore, recent surveys targeting the Malabar Civet had failed to locate them in previously known distribution localities (Nandini \& Mudappa 2010). The distribution of the Fishing Cat in southern India is another doubtful record; however, the species is also reported from Periyar Tiger Reserve, the southwestern boundary of the landscape. In addition, Menon (2009) also sketched the southern Western Ghats as the distribution limit of the species. More intensive sampling employing camera traps may address this unconfirmed distribution record. Although we have not seen the Golden Jackal during our survey, locals and forest department staff have reported that they seldom see the jackal in the plains next to the foot hills. Though we have not quantified threats on mammals, during our study, anthropogenic pressures such as conversion of natural habitats (to monoculture plantations such as coffee, tea, silk cotton etc), encroachment, poaching, cattle grazing and tourism were observed to affect the distribution of mammals in the landscape.

Species richness of mammals in the Meghamalai landscape is comparable with other protected areas/ reserved forests in the eastern slopes of the southern Western Ghats with similar landscape features, viz., Kalakkad-Mundanthurai Tiger Reserve, Grizzled Squirrel Wildlife Sanctuary, Palani Hills and Anamalai Tiger Reserve. The distribution of mammals in Meghamalai is also comparable with a few key sites in the southern Western Ghats such as Periyar Tiger Reserve and Parambikulam Tiger Reserve.

As a positive sign in the conservation initiative of the landscape, a portion of the landscape was recently declared as a wildlife sanctuary. Although Vellimalai, the entire stretch of High Wavy Mountains and high elevation of Varusanad Hills are rich in terms of biodiversity, it is still under the non-protected area category which requires further consideration for management and conservation initiatives.

\section{REFERENCES}

Ashraf, N.V.K., A. Kumar, \& A.J.T. Johnsingh (1993). Two endemic viverrids of the Western Ghats. Oryx 27(2): 109--114; http://dx.doi. org/10.1017/S0030605300020640

Bhupathy, S., G. Srinivas, N. Sathishkumar, M. Murugesan, S. Babu, R. Suganthasakthivel \& P. Sivakumar (2012). Diversity and conservation of selected biota of the Meghamalai landscape, Western Ghats, India. Current Science 102(4): 590--595.

Hutton, A.F. (1949). Notes on the snakes and mammals of the High Wavy mountains, Madura District, South India. Part II-Mammals. Journal of the Bombay Natural History Society 48: 681--694.

Kumara, H.N., R. Sasi, R. Suganthasakthivel \& G. Srinivas (2011). 
Table 1. List of mammals observed in Meghamalai landscape, southern Western Ghats, India

\begin{tabular}{|c|c|c|c|c|c|c|}
\hline & Common name & Scientific name & Endemic & IUCN status & Source & $\begin{array}{l}\text { Meghamalai } \\
\text { status }\end{array}$ \\
\hline & Cercopithecidae & & & & & \\
\hline 1 & Nilgiri Langur & Semnopithecus johnii & WG & Vu & 1,2 & UC \\
\hline 2 & Tufted Grey Langur & Semnopithecus priam & IN & NT & 1,2 & UC \\
\hline 3 & Lion-tailed Macaque (Image 1) & Macaca silenus & WG & EN & 1,2 & $\mathrm{RR}$ \\
\hline \multirow[t]{2}{*}{4} & Bonnet Macaque & Macaca radiata & IN & LC & 1,2 & c \\
\hline & Loridae & & & & & \\
\hline \multirow[t]{2}{*}{5} & Grey Slender Loris & Loris lydekkerianus & & LC & 1,2 & UC \\
\hline & Felidae & & & & & \\
\hline 6 & Tiger & Panthera tigris & & EN & 1,2 & $\mathrm{RR}$ \\
\hline 7 & Leopard & Panthera pardus & & NT & 1,2 & UC \\
\hline 8 & Jungle Cat & Felis chaus & & LC & 1,2 & UC \\
\hline 9 & Leopard Cat & Prionailurus bengalensis & & $\mathrm{LC}$ & 1,2 & $\mathrm{RR}$ \\
\hline 10 & Fishing Cat & Prionailurus viverrinus & & EN & 2 & ? \\
\hline \multirow[t]{2}{*}{11} & Rusty-spotted Cat (Image 2) & Prionailurus rubiginosus & & Vu & 1 & $\mathrm{RR}$ \\
\hline & Canidae & & & & & \\
\hline 12 & Dhole (Image 3) & Cuon alpinus & & EN & 1,2 & UC \\
\hline 13 & Golden Jackal & Canis aureus & & LC & 2 & $\mathrm{RR}$ \\
\hline \multirow[t]{2}{*}{14} & Indian Fox & Vulpes bengalensis & & LC & 1,2 & c \\
\hline & Viverridae & & & & & \\
\hline 15 & Small Indian Civet & Viverricula indica & & LC & 1,2 & UC \\
\hline 16 & Malabar Civet & Viverra civettina & WG & $C R$ & 2 & ? \\
\hline 17 & Common Palm Civet & Paradoxurus hermaphroditus & & LC & 1 & UC \\
\hline \multirow[t]{2}{*}{18} & Brown Palm Civet & Paradoxurus jerdoni & WG & LC & 1,2 & UC \\
\hline & Herpestidae & & & & & \\
\hline 19 & Indian Grey Mongoose & Herpestes edwardsii & & LC & 1 & UC \\
\hline 20 & Ruddy Mongoose & Herpestes smithii & & LC & 1,2 & UC \\
\hline 21 & Indian Brown Mongoose & Herpestes fuscus & & Vu & 1,2 & UC \\
\hline \multirow[t]{2}{*}{22} & Stripe-necked Mongoose & Herpestes vitticollis & & LC & 1,2 & C \\
\hline & Mustelidae & & & & & \\
\hline 23 & Smooth-Coated Otter & Lutrogale perspicillata & & Vu & 1,2 & UC \\
\hline 24 & Asian Small-clawed Otter & Aonyx cinerea & & vu & 1,2 & UC \\
\hline \multirow[t]{2}{*}{25} & Nilgiri Marten & Martes gwatkinsi & WG & Vu & 1,2 & $\mathrm{RR}$ \\
\hline & Sciuridae & & & & & \\
\hline 26 & Indian Giant Squirrel & Ratufa indica & IN & LC & 1,2 & UC \\
\hline 27 & Grizzled Giant Squirrel (Image 4) & Ratufa macroura & & NT & 1 & $\mathrm{RR}$ \\
\hline 28 & Common Palm Squirrel & Funambulus palmaram & & LC & 1,2 & ve \\
\hline 29 & Western Ghats Striped Squirrel & Funambulus tristriatus & WG & LC & 1,2 & c \\
\hline 30 & Dusky-Striped Squirrel & Funambulus sublineatus & & Vu & 1,2 & c \\
\hline 31 & Indian Giant Flying Squirrel & Petaurista philippensis & & LC & 1,2 & UC \\
\hline \multirow[t]{2}{*}{32} & Travancore Flying Squirrel & Petinomys fuscocapillus & & NT & 1,2 & NE \\
\hline & Cervidae & & & & & \\
\hline 33 & Sambar (Image 5) & Rusa unicolor & & vu & 1,2 & c \\
\hline 34 & Southern Red Muntjac & Muntiacus muntjak & & LC & 1,2 & c \\
\hline 35 & Chital & Axis axis & & LC & 1,2 & c \\
\hline
\end{tabular}




\begin{tabular}{|c|c|c|c|c|c|c|}
\hline & Common name & Scientific name & Endemic & IUCN status & Source & $\begin{array}{l}\text { Meghamalai } \\
\text { status }\end{array}$ \\
\hline & Tragulidae & & & & & \\
\hline \multirow[t]{2}{*}{36} & Indian Chevrotain & Moschiola indica & & LC & 1,2 & C \\
\hline & Bovidae & & & & & \\
\hline 37 & Nilgiri Tahr & Nilgiritragus hylocrius & WG & EN & 1,2 & $\mathrm{RR}$ \\
\hline \multirow[t]{2}{*}{38} & Gaur & Bos gaurus & & VU & 1,2 & UC \\
\hline & Suidae & & & & & \\
\hline \multirow[t]{2}{*}{39} & Wild Boar & Sus scrofa & & LC & 1,2 & C \\
\hline & Elephantidae & & & & & \\
\hline \multirow[t]{2}{*}{40} & Asian Elephant & Elephas maximus & & EN & 1,2 & C \\
\hline & Soricidae & & & & & \\
\hline 41 & House Shrew & Suncus murinus & & LC & 2 & $\mathrm{NE}$ \\
\hline \multirow[t]{2}{*}{42} & White-toothed Pygmy Shrew & Suncus etruscus & & LC & 2 & $\mathrm{NE}$ \\
\hline & Erinaceidae & & & & & \\
\hline \multirow[t]{2}{*}{43} & Madras Hedgehog & Paraechinus nudiventris & IN & LC & 1,2 & C \\
\hline & Hystricidae & & & & & \\
\hline \multirow[t]{2}{*}{44} & Indian Crested Porcupine & Hystrix indica & & LC & 1,2 & VC \\
\hline & Manidae & & & & & \\
\hline \multirow[t]{2}{*}{45} & Thick-tailed Pangolin & Manis crassicaudata & & NT & 1,2 & $\mathrm{RR}$ \\
\hline & Ursidae & & & & & \\
\hline \multirow[t]{2}{*}{46} & Sloth Bear & Melursus ursinus & & VU & 1,2 & UC \\
\hline & Leporidae & & & & & \\
\hline \multirow[t]{2}{*}{47} & Indian Hare & Lepus nigricollis & & LC & 1,2 & VC \\
\hline & Muridae & & & & & \\
\hline 48 & Greater Bandicoot Rat & Bandicota indica & & LC & 1,2 & VC \\
\hline 49 & House Rat & Rattus rattus & & LC & 2 & $\mathrm{NE}$ \\
\hline 50 & White-tailed Wood Rat & Madromys blanfordi & & LC & 2 & $\mathrm{NE}$ \\
\hline 51 & Indian Bush Rat & Golunda ellioti & & LC & 2 & $\mathrm{NE}$ \\
\hline 52 & Asiatic Long-tailed Climbing Mouse & Vandeleuria oleracea & & LC & 2 & $\mathrm{NE}$ \\
\hline 53 & House Mouse & Mus musculus & & LC & 2 & $\mathrm{NE}$ \\
\hline \multirow[t]{2}{*}{54} & Little Indian Field Mouse & Mus booduga & & LC & 2 & $\mathrm{NE}$ \\
\hline & Platacanthomyidae & & & & & \\
\hline \multirow[t]{2}{*}{55} & Malabar Spiny Tree Mouse (Image 6) & Platacanthomys lasiurus & WG & $\mathrm{Vu}$ & 1 & $\mathrm{RR}$ \\
\hline & Tupaiidae & & & & & \\
\hline \multirow[t]{2}{*}{56} & Madras Treeshrew & Ananthana elliotti & IN & LC & 2 & $\mathrm{NE}$ \\
\hline & Pteropodidae & & & & & \\
\hline 57 & Indian Flying Fox & Pteropus giganteus & & LC & $1,2,4$ & C \\
\hline 58 & Lesser Dog-faced Fruit Bat & Cynopterus brachyotis & & LC & 3,4 & $\mathrm{NE}$ \\
\hline 59 & Greater Short-nosed Fruit Bat & Cynopterus sphinx & & LC & 2 & $\mathrm{NE}$ \\
\hline \multirow[t]{2}{*}{60} & Sálim Ali Fruit Bat & Latidens salimalii & WG & EN & $1,3,4,5$ & $\mathrm{RR}$ \\
\hline & Rhinolophidae & & & & & \\
\hline \multirow[t]{2}{*}{61} & Rufous Horseshoe Bat & Rhinolophus rouxii & & LC & 5 & $\mathrm{NE}$ \\
\hline & Vespertilionidae & & & & & \\
\hline 62 & Painted Woolly Bat & Kerivoula picta & & LC & 2,4 & NE \\
\hline 63 & Lesser Asiatic Yellow House Bat & Scotophilus kuhlii & & LC & 2,4 & $\mathrm{NE}$ \\
\hline
\end{tabular}

Endemics: $W G=$ Endemic to Western Ghats, IN = Endemic to India; IUCN Status: $C R=$ Critically Endangered, EN = Endangered, VU = Vulnerable,

NT = Near-Threatened, LC = Least Concern; Sources: 1 = Present study (2012), $2=$ Hutton (1949); $3=$ Muni (1994); $4 \& 5=$ Singaravelan \& Marimuthu (2003 a,b); Meghamalai status: $\mathrm{VC}=$ Very Common, $\mathrm{C}=$ Common, $\mathrm{UC}=$ Uncommon, $\mathrm{RR}=\mathrm{Rare}, \mathrm{NE}=$ Not Evaluated, $?=$ Unconfirmed record . 


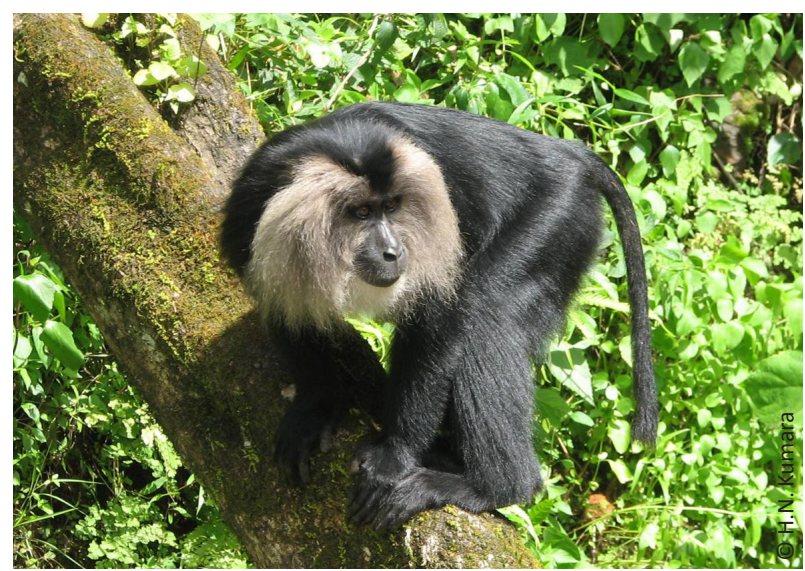

Image 1. Lion-tailed Macaque

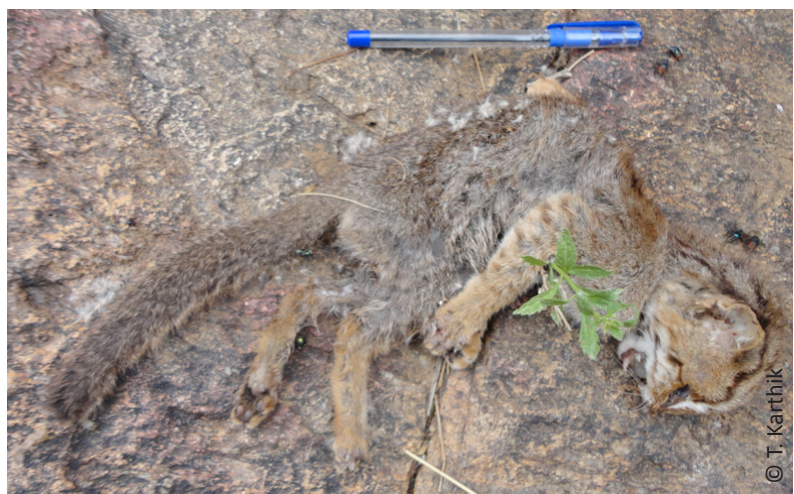

Image 2. Dead specimen of Rusty-spotted Cat

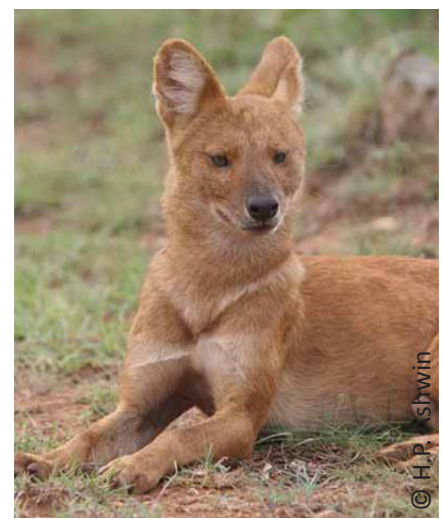

Image 3. Dhole

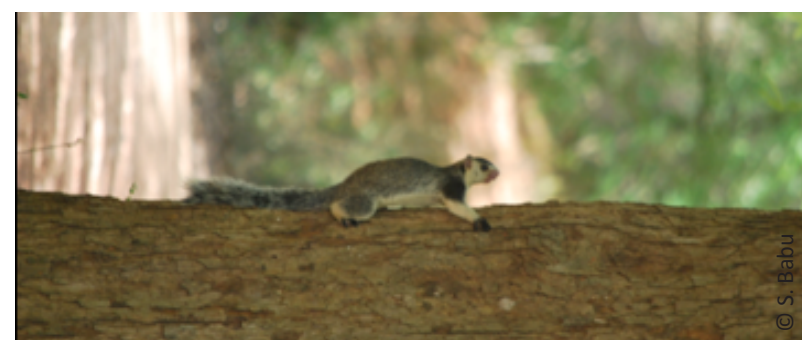

Image 4. Grizzled Giant Squirrel near the Vaigai River

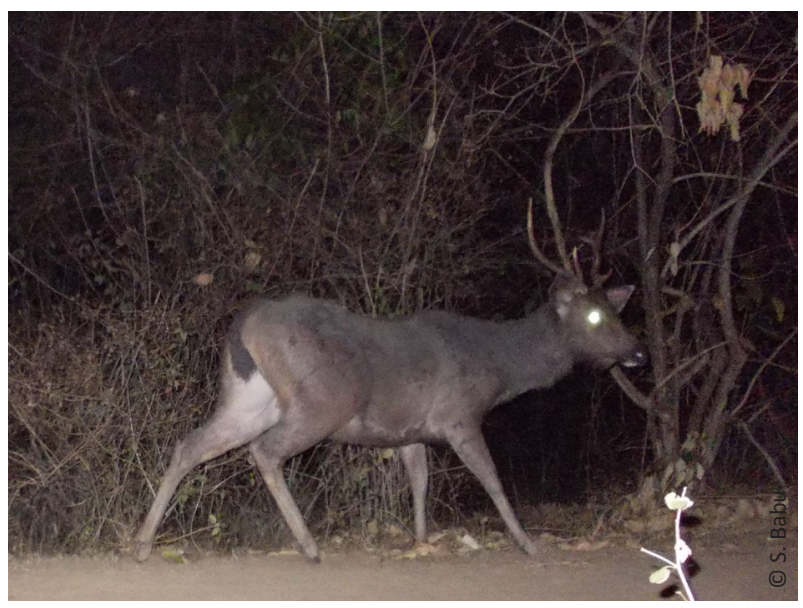

Image 5. Sambar

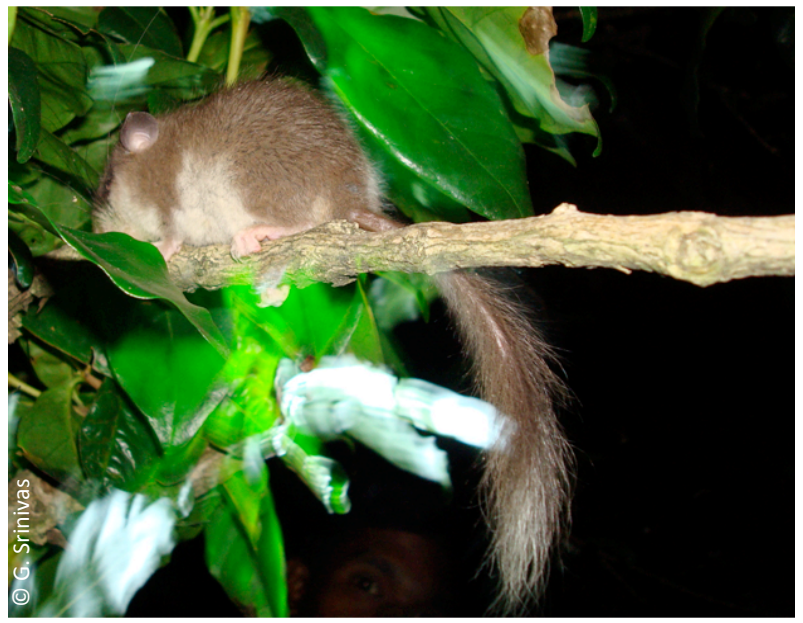

Image 6. Malabar Spiny Tree Mouse

Distribution, abundance and conservation of primates in High Wavy Mountains of Western Ghats, Tamil Nadu, India. Current Science 100: 1063--1067.

Menon, V. (2009). Mammals of India. Princeton University Press, 200pp.

Muni, M. (1994). Rarest of the rare: Latidens salimalii. Hornbill (1): 28--32.

Nandini, R. \& D. Mudappa (2010). Mystery or myth: a review of history and conservation status of the Malabar Civet Viverra civettina Blyth, 1862. Small Carnivore Conservation 43: 47--59.

Singaravelan, N. \& G. Marimuthu (2003a). Discovery of a cave as the day roost of a rarest fruit bat Latidens salimalii. Current Science 84: 1253--1256.

Singaravelan, N. \& G. Marimuthu (2003b). Mist net captures of the rarest fruit bat Latidens salimalii. Current Science 84(1): 24--26.

Thonglongya, K. (1972). A new genus and species of Fruit Bat from south India (Chiroptera: Pteropodidae). Journal of the Bombay Natural History Society 69: 151--158.

Wroughton, R.C. (1917). Bombay Natural History's Mammal survey of India, Burma and Ceylon. Report No.33. High Wavy mountain Madura district. Journal of the Bombay Natural History Society 27: 545--554.

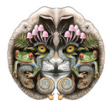

